\title{
METHODOLOGICAL TESTS OF A HETEROTROPHY INDEX FOR AQUATIC ECOSYSTEMS
}

\author{
ANTONIO, R. M. ${ }^{1}$ and BIANCHINI Jr., I. ${ }^{1,2}$ \\ ${ }^{1}$ P. P. G. Ecologia e Recursos Naturais, Universidade Federal de São Carlos, Via Washington Luís, \\ km 235, C.P. 676, CEP 13565-905, São Carlos, SP, Brazil \\ ${ }^{1,2}$ Departamento de Hidrobiologia, Universidade Federal de São Carlos, Via Washington Luís, \\ km 235, C.P. 676, CEP 13565-905, São Carlos, SP, Brazil \\ Correspondence to: Irineu Bianchini Júnior, Departamento de Hidrobiologia, \\ Universidade Federal de São Carlos, Via Washington Luís, km 235, C.P. 676, CEP 13565-905, \\ São Carlos, SP, Brazil, e-mail: irineu@ power.ufscar.br \\ Received March 5, 2002 - Accepted June 7, 2002 - Distributed August 31, 2003
}

(With 4 figures)

\begin{abstract}
Experiments in glucose mineralization were carried out to investigate the effects caused by natural forcing functions on both the decomposition rates and heterotrophy capacity of aquatic ecosystems. In addition, the methodology used could show connections between mineralization rates measured in both laboratory and field work with those measured in aquatic ecosystems. Water samples from Infernão lagoon $\left(21^{\circ} 35^{\prime} \mathrm{S}\right.$ and $\left.47^{\circ} 51^{\prime} \mathrm{W}\right)$ were collected, filtered, enriched with glucose, and incubated under aerobic and anaerobic conditions. The glucose concentration variation, dissolved oxygen (DO) consumption, $\mathrm{pH}$, electric conductivity, and total $\mathrm{CO}_{2}$ amount in the water were determined for sixteen days. In the period with intense oxygen consumption there was also an evident glucose demand and the dissolved oxygen consumption rate was approximately the same as that for glucose mineralization. The process in the aerobic chambers was 2.2 times faster than that in the anaerobic chambers. An initial acidification of the water samples, probably due to microbial carbonic acid liberation, was noted. A rise in $\mathrm{pH}$ values was also observed at the end of the process. The electric conductivity was low for both aerobic and anaerobic chambers, indicating a probable ion uptake by microbial organisms due to the presence of carbon sources. The glucose content variations corresponded to both $\mathrm{CO}_{2}$ formation and dissolved oxygen consumption. It was estimated that $19.4 \%$ of the initial glucose content turned into $\mathrm{CO}_{2}$ and the remaining $80.6 \%$ into humic compounds and microbial biomass. This experiment showed that glucose can be used as a substrate indicating the heterotrophy of a given aquatic ecosystem.
\end{abstract}

Key words: decomposition, mineralization, heterotrophic capacity, aerobic and anaerobic kinetics.

\section{RESUMO}

\section{Teste metodológico de um índice de heterotrofia para ecossistemas aquáticos}

Experimentos de mineralização de glicose foram efetuados para verificar possíveis efeitos causados por fatores condicionantes (funções de força) sobre os coeficientes de decomposição e a capacidade heterotrófica de ecossistemas aquáticos. Esta metodologia foi proposta para estabelecer conexões entre os coeficientes de mineralização obtidos em laboratório e os obtidos a partir de trabalhos de campo. Para tanto, amostras de água da lagoa do Infernão ( $21^{\circ} 33^{\prime} \mathrm{S}$ e $\left.47^{\circ} 51^{\prime} \mathrm{W}\right)$ foram coletadas, filtradas, enriquecidas com glicose e incubadas sob condições aeróbias e anaeróbias. As variações das concentrações de glicose, do consumo de oxigênio dissolvido, do $\mathrm{pH}$, da condutividade elétrica e das concentrações de $\mathrm{CO}_{2}$ total foram determinados por 16 dias. Observou-se que no período em que houve o consumo intenso de oxigênio foi também aquele no qual ocorreu elevado consumo de glicose. $\mathrm{O}$ coeficiente de consumo de oxigênio foi praticamente o mesmo daquele para a decomposição da glicose 
e o processo aeróbio foi 2,2 vezes mais rápido que o anaeróbio. No início do processo, ocorreu acidulação dos meios, provavelmente pela liberação de $\mathrm{CO}_{2}$ por intermédio do metabolismo microbiano. Incrementos nos valores de $\mathrm{pH}$ foram encontrados nos finais dos processos. Para as duas condições experimentais, os valores de condutividade elétrica foram baixos, sugerindo provável assimilação de íons pelos microrganismos. As variações das concentrações de glicose foram de mesmo nível daquelas do consumo de oxigênio. Na mineralização aeróbia, $19,4 \%$ do carbono foi convertido em $\mathrm{CO}_{2}$ e $80,6 \%$ foi transformado em compostos húmicos e biomassa microbiana. Este experimento revelou que a glicose pode ser utilizada como substrato indicador para avaliação do potencial de heterotrofia de determinado ecossistema aquático.

Palavras-chave: decomposição, mineralização, capacidade heterotrófica, cinética aeróbia e anaeróbia.

\section{INTRODUCTION}

In addition to the variety of organisms involved in the decomposition process (Bacteria, Fungi, Actinomycetes, Protozoa, Nematodes, Oligochaetes, Arthropods, Molluca, and Crustacea), specific studies on terrestrial and aquatic ecosystems have shown that immobilization and mineralization depend on the following abiotic factors: 1) temperature (Sorokin \& Kadota, 1972; Brezonik, 1994; Davis \& Cornell, 1991); 2) nutrient contents in the environment and detritus (Hohmann \& Neely, 1993; Carpenter \& Adams, 1979; Coulson \& Butterfield, 1978; Enríquez et al., 1993); 3) detritus type and refracting compounds amount (Mindermann, 1968; Rice \& Tenore, 1981); 4) pH and salinity of the environment (Chan, 1985; Kok \& Van der Velde, 1991; Ogburn et al., 1988); 5) amount of dissolved oxygen (Twilley et al., 1985; Moore Jr. et al., 1992; Gale et al., 1992; Jewell, 1971); 6) detritus particle size (Lush \& Hynes, 1973; Swift et al., 1979; Bianchini Jr. \& Antonio, in prep.). According to Bianchini Jr. (1994), the abiotic conditions of aquatic ecosystems affect degradation, and the nature of decomposition rates results from the synergism of the forcing functions of the ecosystem (Eq. 1).

$\mathrm{k}=\mathrm{f}([\mathrm{N}],[\mathrm{P}],[\mathrm{DO}]$, Temperature, $\mathrm{pH}$, etc.) (Eq. 1) where:

$\mathrm{k} \quad=$ decomposition rate;

$[\mathrm{N}] \quad=$ nitrogen concentration;

[P] = phosphorous concentration;

[DO] = dissolved oxygen concentration.

There are mathematical models describing decomposition processes by plotting the remaining weight or concentration against time, and regression analyses are generally used to compute total decomposition rate. Variations in the decay rates with time, using data from weight loss, result from seasonal interferences, and their effects are cumulative. Conclusions must, therefore, be based on different parts of the same curve corresponding to different steps of the degradation process (Swift et al., 1979).

More sensitive data can be obtained by measuring the immediate oxidation of the resource under controlled temperature, so as to estimate oxygen consumption and carbon dioxide liberation by the aquatic communities involved in the catalytic process (Golterman, 1975). By describing the cause and effect relations of each forcing function over their mineralization rates (Eq. 1), a model was proposed for estimating aquatic ecosystems heterotrophy, which is usually done with litter bag field essays (Bianchini Jr., 1994).

Experiments were designed for exploring theoretical and methodological aspects in order to develop an index describing decomposition rates as the result of forcing functions. Experiments in glucose mineralization were carried out to investigate possible effects caused by man or by natural factors themselves on the cycling rates and on the heterotrophic capacity of aquatic ecosystems. In addition to providing such data, this methodology could show connections between mineralization rates measured in the laboratory with those found in aquatic ecosystems. The aims of this study were: to establish a kinetic model that describes glucose cycling which can be used for the various environmental forcing functions; to verify the kinetics hypothesis assumed with regard to global organic matter cycling; and to measure the effects of the presence of dissolved oxygen on the glucose degradation process. 


\section{MATERIALS AND METHODS}

In the Infernão lagoon (21 $33^{\prime} \mathrm{S}$ and $\left.47^{\circ} 51^{\prime} \mathrm{N}\right)$, a marginal oxbow lake of the Mogi-Guaçu River located in Jataí Ecological Station, Luiz Antônio (São Paulo State, Brazil), a water sample was collected from the bottom, middle, and surface layers using a Van Dorn sampler, and then integrated. At the laboratory, the sample was filtered through glass wool. Three subsamples were then selected; to the first one was added $17 \mathrm{mg} \mathrm{L}^{-1}$ of glucose, to the second, $30 \mathrm{mg} \mathrm{L}^{-1}$; and to the third, the control, no glucose was added.

Two groups of mineralization chambers (flasks) were assembled, one aerobic in which oxygen was dissolved in water and the other one anaerobic, in which hydrogen gas was likewise dissolved. The flasks, with 5 liters of water sample, were covered with aluminum foil to avoid photosynthetic processes and kept at room temperature $\left(23.3 \pm 1.3^{\circ} \mathrm{C}\right)$.

The glucose concentration variation, dissolved oxygen (DO) consumption, $\mathrm{pH}$, electric conductivity, and the total $\mathrm{CO}_{2}$ of the water under aerobic and anaerobic conditions were measured daily until the eighth day, and every two days thereafter until the sixteenth day. Oxygen was dissolved into the water until saturation when, in the mineralization chambers, the DO values of the sample presented a concentration of approximately $2 \mathrm{mg} \mathrm{L}^{-1}$. Temperature and DO were evaluated by an oxymeter, glucose by the colorimetric method (Dubois et al., 1956), total carbon dioxide by the titrimetric method (Golterman \& Clymo, 1971), and $\mathrm{pH}$ and electric conductivity were measured using electrodes.

\section{RESULTS AND DISCUSSION}

The decay of DO concentration was recorded and reoxygenation was induced in the chambers on the fifth day (Fig. 1A). Evident decay of DO contents was observed in the aerobic water with glucose, indicating the higher DO demand due to glucose mineralization (Fig. 1A). Accumulated DO uptake deriving from glucose mineralization and from organic matter in the water sample is shown in Fig. 1B. Higher consumption in the chamber with glucose was found, owing to the complete mineralization of sugar and dissolved organic matter.
The DO uptake for mineralization of the organic matter from the Infernão lagoon was evaluated (by the difference of accumulated DO uptake values), and the data were fitted to a first-order kinetic model (Eq. 2). The DO consumption rate $\left(\mathrm{k}_{1}\right)$ in the glucoseenriched samples (Fig. 1C) was estimated as 0.304 day $^{-1}$ and the total DO uptake amount in the glucose mineralization process $\left(\mathrm{y}_{\infty}\right)$ was $3.51 \mathrm{mg} \mathrm{L}^{-1}$. This value corresponds to a half-life time $\left(\mathrm{t}_{1 / 2}\right)$ equal to 2.28 days. For a $20^{\circ} \mathrm{C}$ temperature, the half-life time can be considered similar to those BOD rates described for well-treated sewage (Davis \& Cornwell, 1991) and for several aquatic systems (EPA, 1985).

$$
\mathrm{y}_{\mathrm{t}}=\mathrm{y}_{\infty}\left(1-\mathrm{e}^{-\mathrm{kt}}\right)
$$

where:

$$
\begin{aligned}
\mathrm{y}_{\mathrm{t}}= & \text { change in accumulated amount of DO } \\
& \text { uptake }\left(\mathrm{mg} \mathrm{L}^{-1}\right) ; \\
\mathrm{y}_{\infty}= & \text { total amount of DO uptake in the pro- } \\
& \text { cess }\left(\mathrm{mg} \mathrm{L}^{-1}\right) ; \\
\mathrm{k}_{1}= & \text { deoxygenation constant rate }\left(\mathrm{day}^{-1}\right) ; \\
\mathrm{t}= & \text { experimental elapsed time. }
\end{aligned}
$$

Water temperature in the mineralization chambers ranged from $21.5^{\circ} \mathrm{C}$ to $26^{\circ} \mathrm{C}$ during the experiments (Fig. 1D). The DO uptake from the third until the seventh day could have been underestimated in relation to the initial ones, due to the temperature drop. The rates obtained may be regarded as corresponding to the mean temperature of the experiment $\left(23.3^{\circ} \mathrm{C}\right)$.

The glucose amount in the two mineralization chambers under an aerobic environment changed with time (Fig. 2A). Glucose concentration decay was noted in the bottle with glucose until the seventh day of the experiment and it was also observed in the reference flask (without glucose) until the fifth day. After the first week of experiments, the contents of glucose and sugar-based substances remained unchanged. In the period of evident DO uptake, there was also a marked glucose demand (Figs. 1A, 1B, and $2 \mathrm{~A}$ ).

Subsequent to removing the content of carbohydrate compounds from the Infernão lagoon, water samples, the data were fitted to a first-order kinetic model: $y_{t}=y_{o} e^{-k t}$ (where: $\mathrm{y}_{\mathrm{t}}=$ change in accumulated amount of glucose $\left(\mathrm{mg} \mathrm{L}^{-1}\right) ; \mathrm{y}_{\mathrm{o}}=$ total amount of added 
glucose $\left(\mathrm{mg} \mathrm{L}^{-1}\right) ; \mathrm{k}_{2}=$ decay constant rate $\left(\right.$ day $\left.^{-1}\right) ; \mathrm{t}=$ experimental elapsed time), and a high correlation coefficient was obtained $\left(r^{2}=0.96\right)$. Thus, the glucose decomposition rate could be determined $\left(\mathrm{k}_{2}=0.309\right.$ day $^{-1}$ ) and the half life of the process was estimated as 2.24 days (Fig. 2B).

Because the rates of DO and glucose consumption are almost the same, and in accordance with the kinetic theory of parallel reactions and the stoichiometry of glucose reactions, it was observed that $19.4 \%$ of the organic carbon (glucose) added to the water sample probably degraded into $\mathrm{CO}_{2}$. As for the remaining $80.6 \%$, it supposedly forms microbial tissues and humic substances. According to similar experiments described by Gaudy Jr. \& Gaudy (1980), the average cellular yield coefficient (glucose conversion into microorganisms) was estimated at $62 \%$. In this case, the remaining $18.6 \%$ are expected to be converted into humic compounds
(Fig. 3). The reaction rates showed in Fig. $3\left(\mathrm{k}_{1}\right.$, $\mathrm{k}_{2}$, and $\mathrm{k}_{3}$ ) were calculated from the integration constant derived from analytical integration of the differential equations set. This set represents parallel first-order kinetics, which considers one reagent (glucose) and three products (inorganic substances, humic compounds, and microorganisms). For this estimate, the data on global decay rates and yields were used (Levenspiel, 1974).

The $\mathrm{pH}$ during the experiments under aerobic conditions ranged from 6.6 to 6.8 in the water with glucose (Fig. 2C). The low values are probably due to microbial activity (oxidation). After the initial stage of the experiment (about 3 days), for both bottles the tendency was to approach stationary values resulting from the action of earlier-formed humic compounds, as found by Bianchini Jr. \& Toledo (1988) for experiments on the decay of aquatic macrophytes.
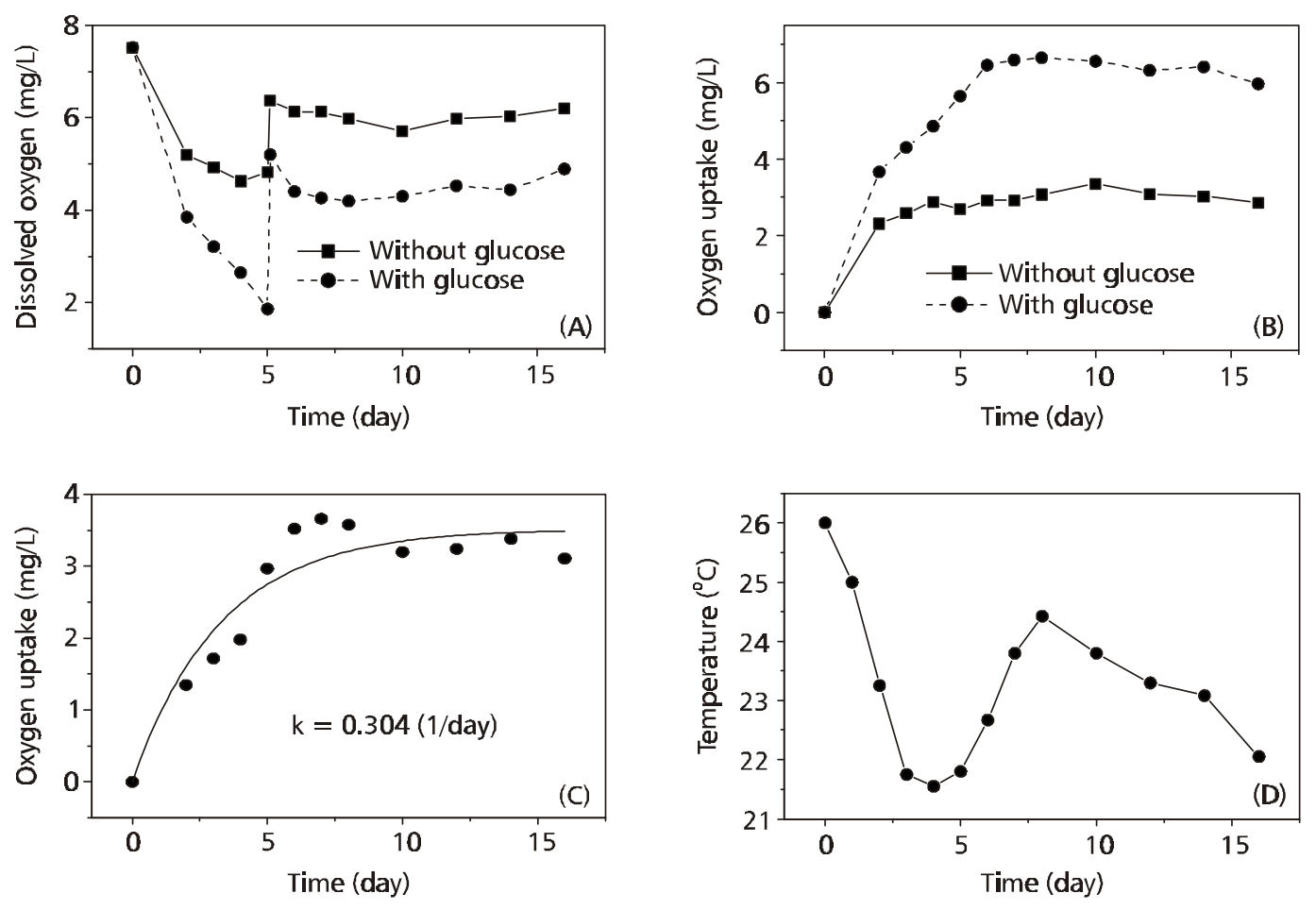

Fig. 1 - Time evolution of: A) dissolved oxygen; B) and C) oxygen uptake; and D) temperature in the bottles under aerobic conditions during the glucose mineralization period. 

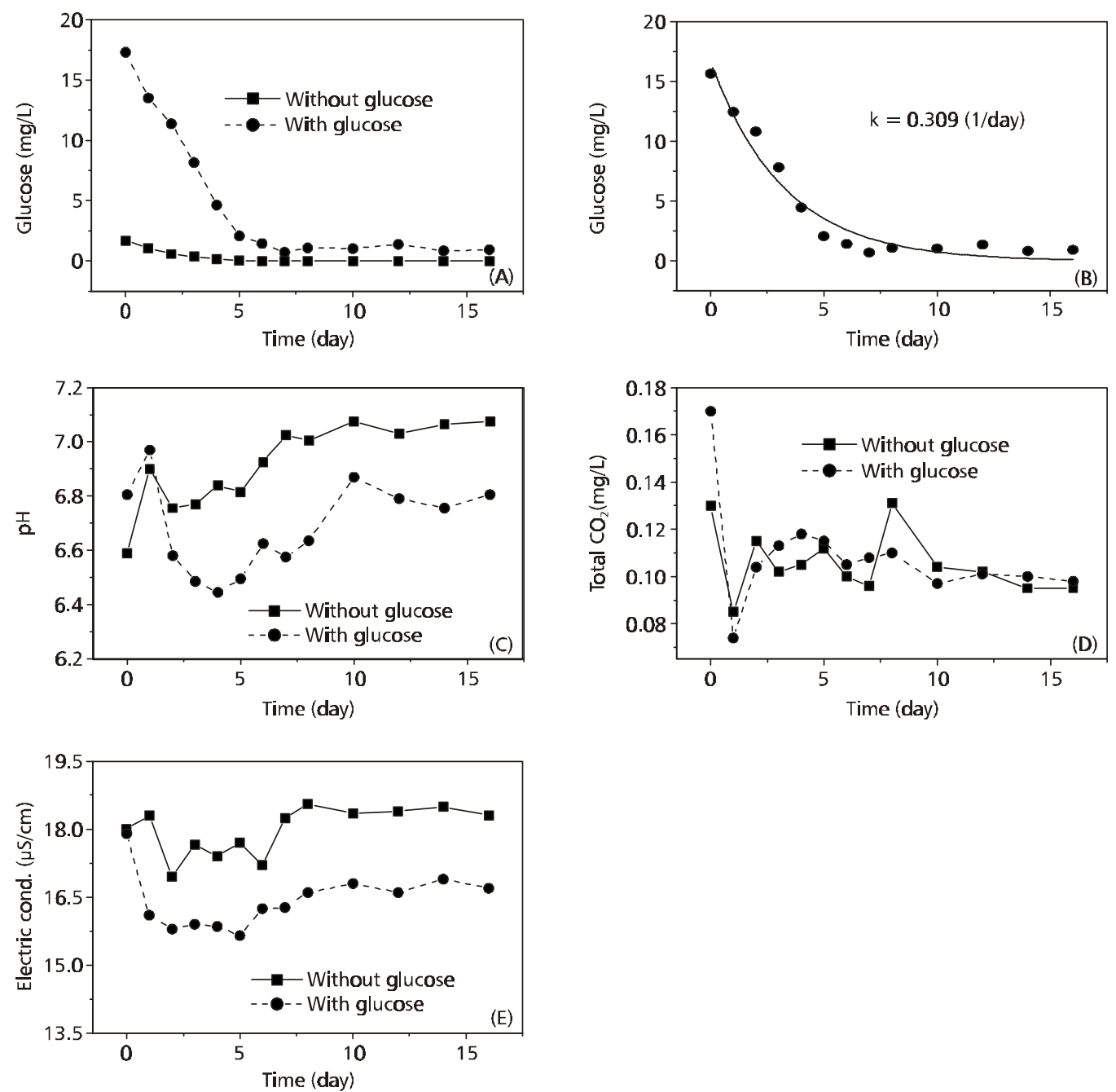

Fig. 2 - Time evolution of: A) and B) glucose concentration; C) $\mathrm{pH}$; D) total $\mathrm{CO}_{2}$; and E) electrical conductivity, during the glucose mineralization process, under aerobic conditions.

A marked utilization of inorganic carbon forms $\left(\mathrm{CO}_{2}, \mathrm{H}_{2} \mathrm{CO}_{3}\right.$ and $\left.\mathrm{HCO}_{3}^{-}\right)$on the first day of experiments was observed (Fig. 2D). After this period, there was a concentration increase owing to glucose oxidation and DOM (Dissolved Organic Matter). The variation of total $\mathrm{CO}_{2}$ (Fig. 3D) and the $\mathrm{pH}$ (Fig. 3C) showed that the total $\mathrm{CO}_{2}$ concentrations seemed to be related indirectly with the $\mathrm{pH}$.

As for the electrical conductivity changes (Fig. $2 \mathrm{E})$, the water with glucose always presented lower conductivity values than did those for water without glucose. This indicates ion incorporation through microbial activity, due to the availability of carbon sources (Antonio et al., 1999; Cunha-Santino \& Bianchini Jr., 2002). The glucose concentration time variations in two mineralization chambers maintained under anaerobic conditions are shown in Figure 4A. Marked decay is shown until the eighth day of the experiment in the bottle with glucose, after which concentration stabilized at a low value. 


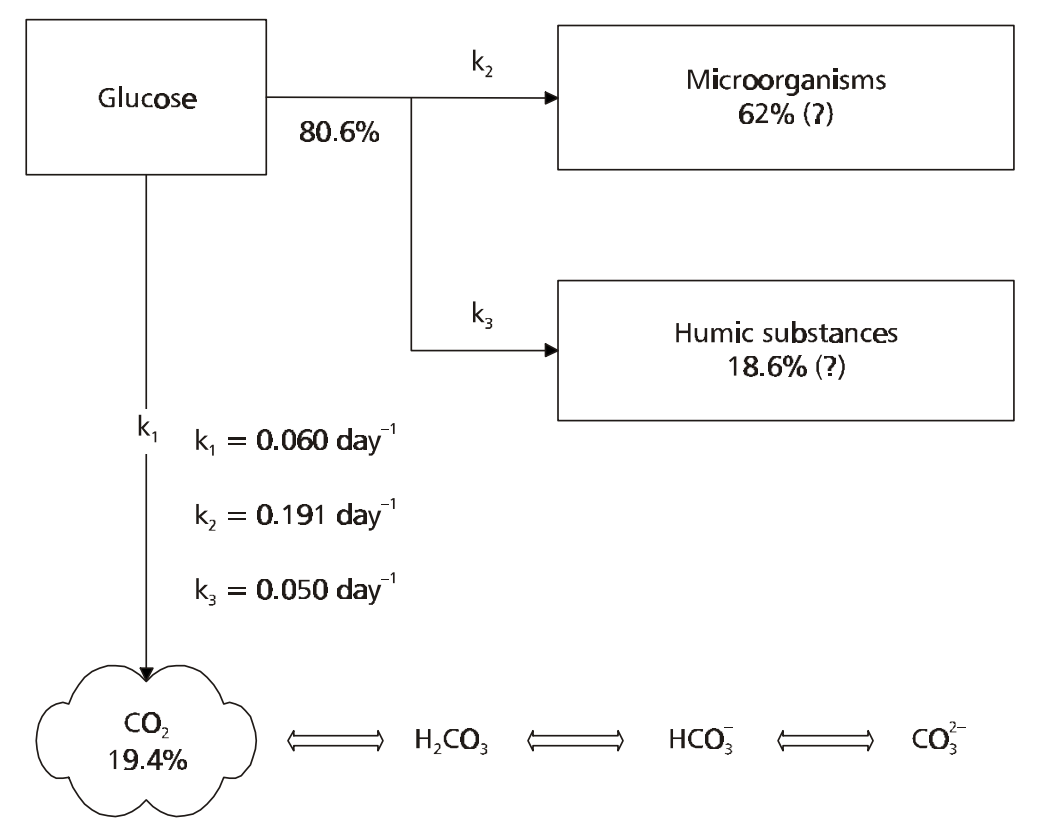

Fig. 3 - Proposed pathways for the glucose decomposition process under aerobic conditions.

The bottle without glucose (reference flask) always presented low glucose concentration values and low decay was observed until the second day of the experiment.

After removing the carbohydrate content of the samples from the Infernão lagoon (Fig. 4A), the data were fitted to a first-order kinetics model (Fig. 4B), and a high correlation was obtained $\left(\mathrm{r}^{2}=0.90\right)$. The glucose decomposition rate under anaerobic conditions corresponded to 0.143 day $^{-1}$; the half life of the process was 5.0 days.

When the initial and final values of the glucose vs. time curve, which could represent the lag and stabilization phases of the curve, are not taken into account (Fig. 4B), and only the log phase is considered, the decomposition rate for the processes under anaerobic conditions becomes 0.224 day $^{-1}$. This procedure could be adopted when lag and stationary phases are easily identified. However, in the present work, this approximation was not adopted; the exponential model was applied for both conditions. Comparing the results of aerobic and anaerobic decay of glucose, the aerobic process was observed tobe 2.2 times faster. This comparison provides an indication of the dissolved oxygen status in the Infernão lagoon and also shows aerobic microorganism predominance in the sampled water.

The variation of $\mathrm{pH}$ values in the bottles under anaerobic conditions appears in Figure 4C. As in the experiment under aerobic conditions, the bottle with added glucose showed lower $\mathrm{pHs}$ than did the reference. The $\mathrm{pH}$ varied from 6.6 to 7.05 in the water sample with glucose and from 6.3 to 7.0 in the water without glucose. These values suggest higher $\mathrm{H}_{2} \mathrm{CO}_{3}$ formation (by microbial activity) and some other predominant inorganic carbon $\left(\mathrm{CO}_{2}\right.$, $\mathrm{HCO}_{3}^{-}$) forms in the bottle to which glucose was added. Marked decay from the first day and a little recovery during the remaining period of the experiments were observed (Fig. 4D).

As noted for the experiments carried out under aerobic media, in the anaerobic group electric conductivity was lower in the bottle with glucose (Fig. 4E). Higher ion uptake through microbial activity was probably due to available carbon sources in the water. 

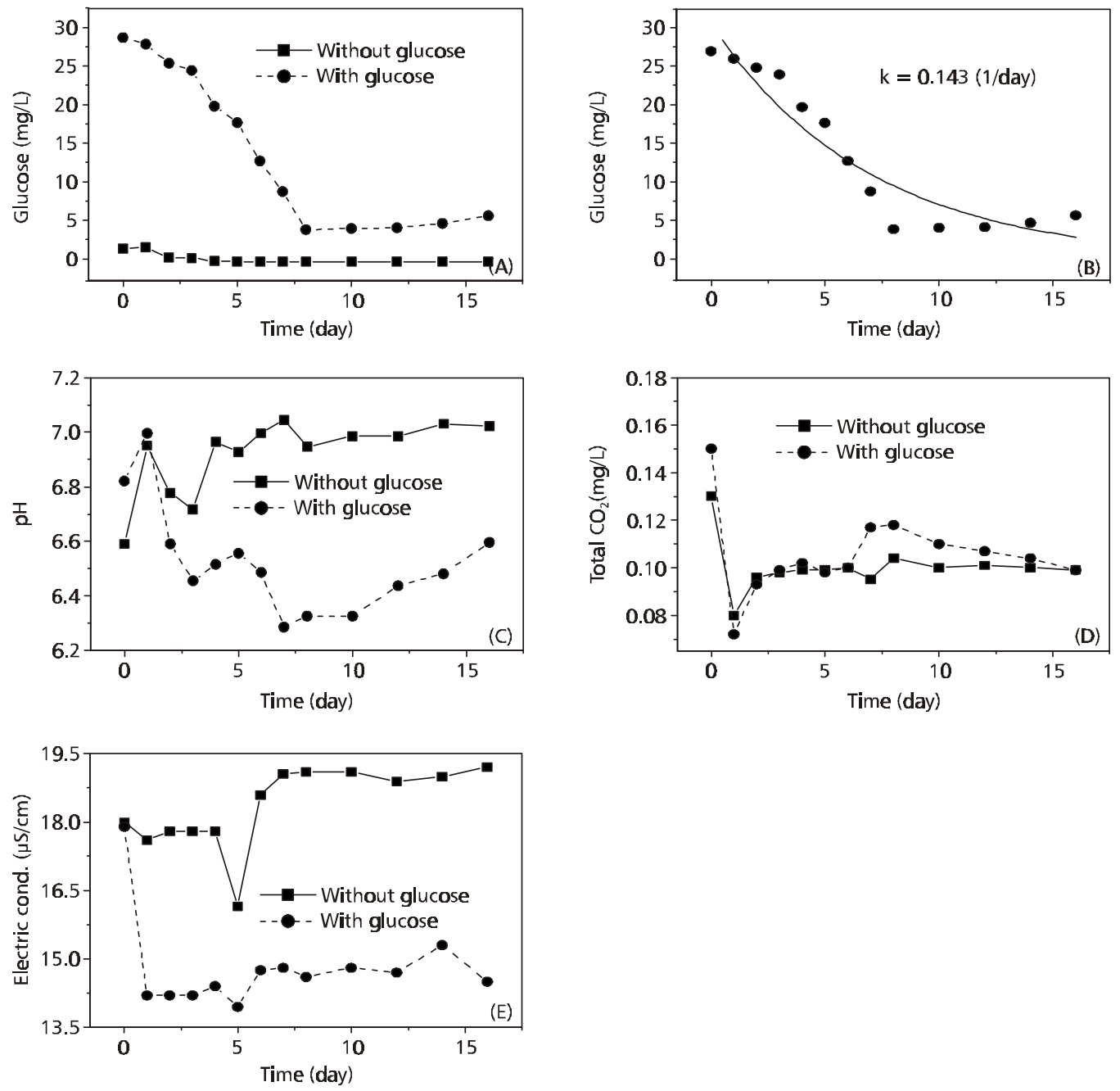

Fig. 4 - Time evolution of: A) and B) glucose concentration; C) $\mathrm{pH}$; D) total $\mathrm{CO}_{2}$; and E) electrical conductivity, during the glucose mineralization process, under anaerobic conditions.

\section{CONCLUSIONS}

Under the experimental conditions, one may conclude that: 1) variation (decay) of the glucose concentration was related to both $\mathrm{CO}_{2}$ formation and DO uptake and thus glucose may be used as an indicator substrate of heterotrophy in the Infernão lagoon; 2) the method was sufficiently sensitive to distinguish between aerobic and anaerobic conditions; 3) the decomposition rate found for the aerobic process was higher than that found under anaerobic conditions; 4) considering the initial values of the glucose for aerobic conditions, $19.4 \%$ was converted into $\mathrm{CO}_{2}$, and the remaining $80.6 \%$ transformed into humic compounds and microbial biomass. These results suggest that glucose can be used as a substrate indicating heterotrophy in a given aquatic ecosystem.

Acknowledgments - The authors thank Fundação de Amparo à Pesquisa do Estado de São Paulo (FAPESP) for financing these essays (Process n. 91/1303-3) and Dr. Osvaldo N. Oliveira Jr. (IFSC-USP) for proofreading the manuscript. 


\section{REFERENCES}

ANTONIO, R. M., BITAR, A. L. \& BIANCHINI Jr., I., 1999, Consumo de oxigênio na mineralização de folhas, galhos, cascas e serapilheira. Acta Limnol. Brasil., 11(2): 1-16.

BIANCHINI Jr., I., 1994, Estudo da dinâmica de detritos do lago Infernão: modelo cinético da decomposição de Scirpus cubensis. Relatório Técnico no 2 2. Proc. FAPESP no 91/13013, São Carlos, SP

BIANCHINI Jr., I. \& TOLEDO, A. P. P., 1988, Decomposição de macrófitas aquáticas - estudo da variação do $\mathrm{pH}$ e densidade óptica em ensaios sob diferentes condições de atmosfera e luminosidade. An. Sem. Reg. Ecol. V, São Carlos, SP, pp. 167-181.

BIANCHINI Jr., I. \& ANTONIO, R. M. (in prep.), The effect of particle size on the leaching of Scirpus cubensis Poepp \& Kunth.

BREZONIK, P. L., 1994, Chemical kinetics and process dynamics in aquatic systems. Lewis, Boca Raton, 754p.

CARPENTER, S. R. \& ADAMS, M. S., 1979, Effects of nutrients and temperature on decomposition of Myriophylum spicatum L. in a hard water eutrophic lake. Limnol. Oceanog., 24: 520-528.

CHAN, K., 1985, Aerobic decomposition of Chlorella salina in freshwater and saline conditions. Hydrobiol., 122: 35-44.

COULSON, J. C. \& BUTTERFIELD, J., 1978, An investigation of the biotic factors determining the rates of decomposition on a blanket bog. J. Ecol., 66: 631-650.

CUNHA-SANTINO, M. B. \& BIANCHINI Jr., I., 2002, Estequiometria da decomposição aeróbia de galhos, cascas serapilheira e folhas, pp. 185-197. In: E. Espíndola (org.), Recursos hidroenergéticos: usos, impactos e planejamento integrado. RiMa, São Carlos.

DAVIS, M. L. \& CORNWELL, D. A., 1991, An introduction to environmental engineering. McGraw-Hill, New York, 822p.

DUBOIS, M., GILLES, K., HAMILTON, J. K., REBERS, P. A. \& SMITH, F., 1956, Colorimetric method for determination of sugar and related substances. Anal. Chem., 28: $350-356$.

ENRÍQUEZ, S., DUARTE, C. M. \& SAND-JENSEN, K., 1993, Patterns in decomposition rates among photosynthetic organisms: the importance of detritus C:N:P content. Oecologia, 94: 457-471.

EPA. UNITED STATES ENVIRONMENTAL PROTECTION AGENCY, 1985, Rates, constants, and kinetics formulations in surface water quality modeling. EPA/600/3-85/40, Athens, 2 ed., $455 \mathrm{p}$

GALE, P. M., REDDY, K. R. \& GRAETZ, D. A., 1992, Mineralization of sediment organic matter under anoxic conditions. J. Environ. Qual., 21: 394-400.
GAUDY Jr., A. F. \& GAUDY, E. T., 1980, Microbiology for environmental scientists and engineers. McGraw-Hill, New York, 736p.

GOLTERMAN, H. L. \& CLYMO, R. S., 1971, Methods for chemical analysis of fresh water. IBP n. 8. Blackwell, Oxford, 166p.

GOLTERMAN, H. L., 1975, Physiological limnology. Elsevier, Amsterdam, 489p.

HOHMANN, J. \& NEELY, R. K., 1993, Decomposition of Sparganium eurycarpum under controlled $\mathrm{pH}$ and nitrogen regimes. Aqua. Bot., 46: 17-33.

JEWELL, W. J., 1971, Aquatic weed decay: dissolved oxygen utilization and nitrogen and phosphorus regeneration. $J$. Wat. Poll. Contr. Fed., 43: 1457-1467.

KOK, C. J. \& VAN der VELDE, G., 1991, The influence of selected water quality parameters on the decay rate and exoenzymatic activity of detritus of Nymphaea alba L. floating leaf blades in laboratory experiments. Oecologia, 88: 311-316.

LEVENSPIEL, O., 1974, Engenharia das reações químicas. Edgard Blücher, São Paulo, 1ํvol., $211 \mathrm{p}$.

LUSH, D. L. \& HYNES, H. B. N., 1973, The formation of particles in freshwater lecheates of dead leaves. Limnol. Oceanog., 18: 968-977.

MINDERMANN, G., 1968, Addition, decomposition and accumulation of organic matter in forests. J. Ecol., 56: 355562 .

MOORE Jr., P. A., REDDY, K. R. \& GRAETZ, D. A., 1992, Nutrient transformations in sediments influenced by oxygen supply. J. Environ. Qual., 21: 387-393.

OGBURN, R. W., BREZONIK, P. L. \& DELFINO, J. J., 1988, Effect of $\mathrm{pH}$ on phosphorus release during macrophyte (Eleocharis $s p$ ) decomposition. Water Resour. Bull., 23: 829-832.

RICE, D. L. \& TENORE, K. R., 1981, Dynamics of carbon and nitrogen during the decomposition of detritus derived from estuarine macrophytes. Estuarine, Coastal and Shelf Science, 13: 681-690.

SOROKIN, Y. I. \& KADOTA, H., 1972, Techniques for the assessment of microbial production and decomposition in fresh waters. IBP n. 23, Blackwell, Oxford, 112p.

SWIFT, M. J., HEAL, D. W. \& ANDERSON, J. M., 1979, Studies in ecology-decomposition in terrestrial ecosystems. Blackwell, Oxford, 371p.

TWILLEY, R. R., EJDUNG, G., ROMARE, P. \& KEMP, W. M., 1985, A comparative study of decomposition and nutrient release for selected aquatic plants occurring in an estuarine environment. Oikos, 47: 190-198.

WETZEL, R. G, 1983, Limnology. Saunders, Philadelphia, 767p. 